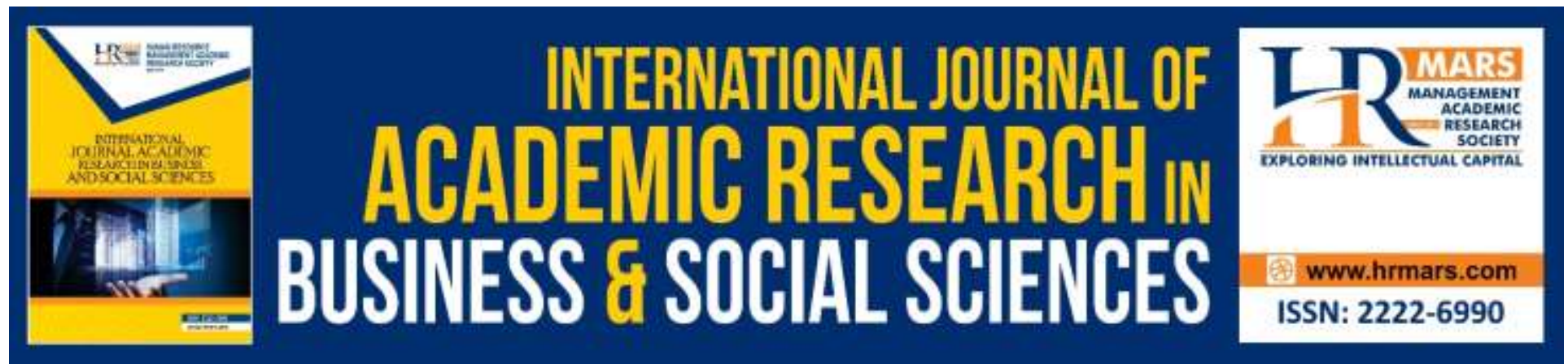

\title{
Usages - Source of Civil Law in the Regulation of the Romanian Civil Code
}

Ilie-Catalin Ungureanu

To Link this Article: http://dx.doi.org/10.6007/IJARBSS/v8-i5/4392

DOI: $10.6007 /$ IJARBSS/v8-i5/4392

Received: 20 Feb 2018, Revised: 25 Mar 2018, Accepted: 05 April 2018

Published Online: 08 May 2018

In-Text Citation: (Ungureanu, 2018)

To Cite this Article: Ungureanu, I. C. (2018). Usages - Source of Civil Law in the Regulation of the Romanian Civil Code. International Journal of Academic Research in Business and Social Sciences, 8(5), 977-985.

Copyright: (c) 2018 The Author(s)

Published by Human Resource Management Academic Research Society (www.hrmars.com)

This article is published under the Creative Commons Attribution (CC BY 4.0) license. Anyone may reproduce, distribute, translate and create derivative works of this article (for both commercial and non-commercial purposes), subject to full attribution to the original publication and authors. The full terms of this license may be seen

at: http://creativecommons.org/licences/by/4.0/legalcode

Vol. 8, No. 5, May 2018, Pg. 977 - 985

http://hrmars.com/index.php/pages/detail/IJARBSS

JOURNAL HOMEPAGE

Full Terms \& Conditions of access and use can be found at http://hrmars.com/index.php/pages/detail/publication-ethics 


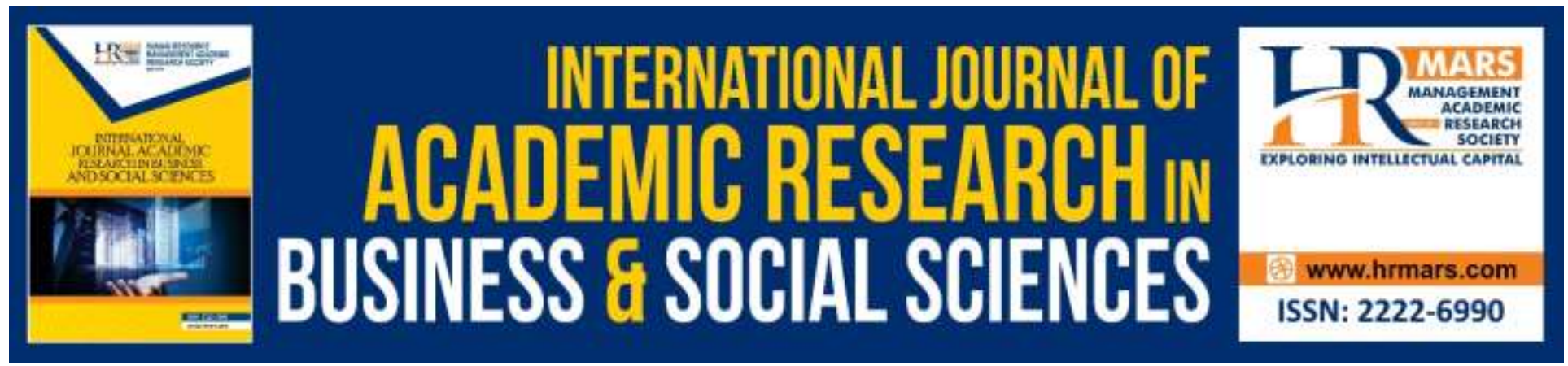

\title{
Usages - Source of Civil Law in the Regulation of the Romanian Civil Code
}

\author{
Ilie-Catalin Ungureanu \\ Juridical Researches Institute, Romanian Academy, Romania \\ Email: avocatcatalinungureanu@yahoo.com
}

\begin{abstract}
The role of custom in the formation of modern law is undeniable. The evolution of social relationships and structures, as well as the need for legal stability and predictability have diminished the importance of habit in ordering legal relations. The present study aims at analysing the role of custom in Romanian private law. The issue is particularly important, especially since the new Civil Code, which entered into force on October 1, 2011, mentions usage as a source of subsidiary civil law and subordinate to the law. Many authors considered this regulation to be an anachronistic one, a return to the past. However, through a careful analysis of the regulation contained in the Civil Code, it can be concluded that this was necessary from the point of view of uniformity in the application of international trade usages in the context of globalized trade. Thus, although custom has always played an extremely important role in public international law (e.g. diplomatic usages), there is a tendency to accept it as a distinct source of law in the legal relations of private law as well.
\end{abstract}

Keywords: Usages, Custom, Professionals, Professional Usage, Habit

\section{Usages - Source of Civil Law in the regulation of the Romanian Civil Code}

Usages (also called custom or habit) are rules of conduct that have crystallized over time in the practice of social life and sometimes tend to become rules of law. It has been said that the power of constraint of custom comes from the belief that the practice it imposes has been the origin of a gesture of a deity or a hero. The custom (usage) is a rule of unwritten conduct that emanates from the social body whose members comply with this rule that they consider binding (Ungureanu and Munteanu 2013).

The custom is at the origin of written law. Our knowledge of the role of custom in Roman law - viewed as a jurisprudential body that applied both during the Republic and during the Western and Eastern Empire (app. 700 BC - 700 AD) - comes from a series of written sources. These texts were taken over in various forms in the European civil law as part of the Western legal tradition. From the compilations of Emperor Justinian - The Institutes, the Digests and the Code - some conclusions can be drawn that highlight the role of customary law as a positive source of legal obligations. 
For example, in the Justinian Institutes it is explicitly stated that "the unwritten law is that which usage has confirmed, for customs long observed and sanctioned by the consent of those who employ them, resemble law" (Institutes of Justinian 1.2.9 in Bederman, 2010). Therefore, the custom was considered as part of the "unwritten law" (ius non scriptum), and this circumstance is in line with the early jurisprudence of the Roman Republic, derived from Greek philosophical sources (Schiller, 1938). The old Roman tradition accepts that mandatory legal sources are derived from "statutes, Senate resolutions, opinions of law specialists, magistrates' edicts, custom and equity" (Bederman, 2010). Therefore, even in Roman early jurisprudence, the custom was considered as part of the positive law and not as a form of the natural law (ius naturale). As we have shown, the Institutes specifically stated the formation of the custom through the "usage" (usus) of the "ancient customs" (mores) sanctioned by the consent (consensu) of those who adopted them."

Roman law has provided a rich material for future legal generations regarding the role of custom as a source of law - its formation, character and relative normative authority. After rediscovering Roman law as a source of knowledge in European medieval universities, an intellectual effort was made to integrate its principles into the bodies of law created by the Catholic Church (canon law) and in the various rules applicable in Western Europe. Ius commune constituted a pan-European mixture of norms inherited from Roman law, from the newly formed canon law and from the pre-existing customary regimes. As suggestively shown by Professor J. Bederman "the medieval common law (ius commune) was a cultural bridge of the Western legal tradition with the Roman law at a temporal end and with the modern legal systems of nationstates at the other" (Bederman, 2010).

In the case of Romanian law, the role of custom in ordering social relations was more pronounced than in Western Europe. The traditional form of organization of the Romanian medieval communities was the commune (Ro "obstea") (Cernea and Molcuţ, 1994) ${ }^{1}$. The existence of the communes also led to the maintenance of the traditional norms based on which they functioned, reinforced by the authority of the political apparatus. Thus they became legal norms of customary origin and new state regulations created under the conditions of centralization of political power were added to them.

The ancient Romanians called these norms a "law" in the sense of unwritten norms, as stated by C.Noica (Cernea and Molcuţ, 1994), a term derived from the Latin re-ligio, that is to bind from within, through faith and conscience, what mos (habit, custom) was for the Romans. Therefore, the norms formed within the commune were respected due to the unanimous consensus of the entire community.

For the Romans, lex meant only the written law, as it derives from the word legere (to read), being imposed on the community by an external constraint, that of the political apparatus.

The written law began to be called law with the emergence of "pravile" - the first Romanian codes of written laws - that appeared in the $17^{\text {th }}$ century, when it was also revealed the difference between written law and unwritten law, which was mostly called habit. As an example, Matei Basarab's Pravila stated that "Where there is no written law, we must protect the custom of the place". For a habit to be considered as having the power of a law, it should have a long

\footnotetext{
${ }^{1}$ The work community organized for the best unfolding of its forms of work.
} 
applicability (Vasilescu et al., 2013)2 and be recognized and accepted by those who apply it - "to be old and approved" (Alexandresco, 1926).

The first modern civil law of Romania, the Civil Code adopted in 1864 after the French one in 1804, limited the role of the custom, indicating its application only in strictly determined cases. Professor D. Alexandresco noticed that "Customary law no longer has in the current law the importance it had in the past, for in our present law, judges can no longer refer to a habit, no matter how constant it is, except in cases specifically determined by law"1" (Alexandresco, 1926). The same author also referred to the applicability of commercial usages, saying that "usages no longer have the power of a law in today's commercial matters either, because Article 1 of the Commercial Code stipulates, contrary to the corresponding text in the Italian code, that where commercial law is silent, the civil law applies. Romanian judges will be able to apply foreign usages as well as foreign law every time they will be called upon to rule on a contract concluded in a country where commercial usage has legal force, for example: England, Italy, etc. Therefore, in our country only usages and habits established by the positive law have the power of law, and only the violation of such a custom may lead to annulment, because in that case the law itself has been violated" (Alexandresco, 1926).

As can be seen, the inter-war legal doctrine denies the custom's nature as independent source of law (both in civil and commercial matters). It could be considered an indirect source of law and was applicable only when the written law referred to it, being therefore incorporated into that norm and recognized not only by its recipients but also by the state power, which gave it legitimacy.

After the Romanian Communist regime was established in 1947, the Romanian Civil Code had a very limited applicability and only in relation to those social relations that were not considered to be in contradiction with the new socialist order. At that time as well, the doctrine was concerned with the role of custom as part of the sources of law. Thus, it was said that "in order to solve the question of the value of habit as a source of law, it is necessary to distinguish between the habits that represent an unhealthy remnant of the past and against which the state is struggling by its laws, in the light of the content of the norm constituting the custom, habits where the attitude of the state is legally indifferent and which, if it combats, it does not do this by means of constraint, but by moral means of persuasion (whose legal recognition would, however, be in contradiction with the State's policy of combating them with non-legal means) and, finally, the habits that the state sanctions, giving them binding legal power. It is obvious that only the latter can be a source of law, a value that is conferred to them by the reference the law makes in some of its provisions to the new customs ${ }^{4}$. Finally, we must also remember cases where the habit

\footnotetext{
${ }^{2}$ A certain habit, however widespread, does not become, through the simple fact of its generalized and long-lasting practice, a legal custom. Thus, for example, offering gifts on different occasions has become a generalized habit, but not a legal one. A habit can only be converted to the law in so far as those who conform to that habit regard it and accept it as a rule of law. That is why from a doctrinaire perspective it is appreciated that the legal habit (custom) presupposes a material element, materialized in the long repetition of a certain practice and a psychological element, concretized in the belief that it is acting by virtue of a mandatory rule.

3 The author referred to Article 529, 532, 600, 607, 610, 970, 981, 1359, 1443, 1436, 1450, 1451 of the 1864 Civil Code that allowed the custom (habit) to be applied in the area of neighbourhood relations or in contractual matters. 4 There are quoted Articles 970 para. (2), 1450, 600, 607, 610 and 1080 of the 1864 Civil Code, to which I have referred above.
} 
INTERNATIONAL JOURNAL OF ACADEMIC RESEARCH IN BUSINESS AND SOCIAL SCIENCES

Vol. 8, No. 5, May 2018, E-ISSN: 2222-6990 @ 2018 HRMARS

(custom) has the direct value of a source of law. Examples of this kind are especially found in maritime law, where the so-called "interpretative usages" (practices of different ports) are an important source of law, and are often "encoded" in the regulations of the usages of different ports" (Eminescu, 1967).

In the same period, professor Gheorghe Beleiu stated: "we consider that only the habits to which the legal texts expressly refer have values of civil law sources, but in such cases such habits are incorporated by the normative act in question, so that they are not separate sources from the normative acts" (Beleiu, 1987).

It is noticed that the approach is not very different from the doctrinal solutions promoted in the inter-war period. The custom sanctioned by the state and embedded in the normative act is still accepted as a source of law. However, contrary to the state's passive attitude towards the custom in the inter-war period, the socialist doctrine identified some habits as "unhealthy remains of the past" that had to be eradicated. Thus, at the theoretical level, a distinction was made between:

- the custom mandatory by virtue of law, by delegation of law (secundum legem) that cannot be challenged as a source of law, because its power comes from the law;

- the "praeter legem" custom or the indifferent custom that the state does not combat with legal means, nor does it sanction. The socialist doctrine, however, stated that it must be "straightened" by moral, persuasive means;

- the "contra legem" custom, which opposes the law and which was seen as a harmful habit, requiring eradication.

The fall of the communist regime and the establishment of the rule of law, based on the market economy, revived the application of the rules of the 1864 Civil Code. The new democratic Constitution of Romania adopted in 1991 recognized the value of habit (custom) as a source of law, stating it explicitly. Thus, Article 44 para. (7) of the Constitution states that "the right to property shall entail the observance of the duties concerning environmental protection and ensuring good neighbourliness and the observance of other duties which, according to law or custom, belong to the owner". Therefore, in the field of property law, and in particular in the area of neighbourhood relations, the constituent legislator recognized the long-standing application of customs and the need to observe them. Since they could not be eradicated even by the oppressive communist regime, they were recognized by the fundamental law of the country.

However, the legal doctrine did not have a fundamentally different approach to the role of custom as a source of law. Further, the distinction between the customs expressly referred to by a series of normative acts and which cannot be considered as separate sources of law, being embedded in the above, and the customs which are not expressly referred to by the law does and which "can be used in the interpretation of legal acts" (Beleiu, 2005).

In the first category there were primarily mentioned those included in the regulation of the 1864 Civil Code. Thus, according to Article 970 of the 1864 Civil Code, the conventions "obligate not only to what is expressly stipulated within themselves, but to all the consequences that the equity, habit or law impose on the obligation, depending on its nature", and Article 1447 stipulated that "Small repairs, called household repairs, which are the responsibility of the lessee, unless stipulated otherwise, are those which the custom of the place considers as being this way...". 
Also, according to Article 980 of the 1864 Civil Code "Doubtful provisions are interpreted according to the custom of the place where the contract was concluded".

In the area of neighbourhood relations the situation of the common fence or wall was mentioned, in which case Article 600 of the Civil Code stated that the height is decided by the "private regulations", and according to Article 607, the distance between the trees planted on two neighbourhoods is established by special rules or determined "by constant and recognized habits".

In the category of habits that could be considered a source of law, the "interpretative usages" applicable in maritime law, which were said to be "codified" in the regulations of the different ports, were still mentioned (Beleiu, 2005).

The habit (custom) was still marginalized from a doctrinal point of view, and this approach suggested that it was about to be excluded from the category of sources of civil law. That conception was synthesized as follows: "It is to be remembered that habit is less and less used, and this is explicable if it is taken into account that habit is the legal expression of slow-moving orders. On the other hand, the principle of legality also requires that the regulation of social relations be done through normative acts adopted by legislative bodies" (Beleiu, 2005).

However, contrary to the doctrinal opinions expressed, there have been cases where "contra legem" customs have been applied as well. This is, for example, the case of the manual gift custom, which was a donation of movable goods made by mere handing-over (hand-in-hand), consequently without an authentic form ${ }^{5}$. However, its validity was recognized, although the authentic form was imperative for donations; in this case we are in the presence of a custom contrary to an imperative norm (Ungureanu and Munteanu, 2013).

Surprisingly, the new Civil Code, which came into force on October $1^{\text {st }} 2011$, specifically includes usages in the category of sources of civil law. According to Article 1 of the Civil Code, entitled "Sources of Civil Law", "(1) The sources of civil law are the law, the usages and the general principles of law. (2) In the cases not provided by the law, usages shall apply and, in their absence, the legal provisions regarding similar situations shall apply, and when such provisions do not exist, the general principles of law shall apply. (3) In matters governed by law, usage applies only insofar as the law expressly refers to it. (4) Only usages in accordance with public order and goodwill morals are recognized as sources of law. (5) The interested party must prove the existence and content of the usages. Usages published in collections elaborated by the entities or bodies authorized in the field are presumed to exist until proved otherwise. (6) For the purposes of this Code, "usages" shall mean the habit (custom) and professional usages".

It is noticed that the new Civil Code uses the notion of "usage" that encompasses the habit (custom) (practices that apply between individuals who do not have a certain quality) and professional usages (practices that apply between professionals). Professional shall mean in the new Civil Code "all those who exploit an enterprise" and by exploiting an enterprise "the systematic exercise by one or more persons of an organized activity consisting in the production, administration or alienation of goods or in the provision of services, whether or not it has a lucrative purpose"(Article 3 para (3) of the Civil Code). The regulation of civil and commercial relations in a single code is the result of a so-called "monist conception" adopted by the editors of the new civil law and requires a unitary regulation of legal relations of private law. From our

\footnotetext{
${ }^{5}$ Under the old civil law "All donations are made by authentic document" (Article 813).
} 
point of view, this approach has effects only in terms of the systematization of private law matters and does not influence the configuration and particularities of the combined branches of law (commercial law, family law, etc.). The old trade regulation also stated that "the present law applies to trade. Where it does not have appropriate provisions, the Civil Code shall apply" (Article 1 of the Commercial Code). Therefore, the civil code and the commercial code were interconnected under the old regulation, civil law being considered as common to commercial law and having direct applicability in matters that were absent from the commercial regulation.

In the new civil regulation, usages are secondary law sources, subordinate to the law. Thus, the "praeter legem" usages (those to which the law does not expressly refer) shall apply directly if there is no legal regulation in a particular matter. In this respect, Article 1 para. (2) of the Civil Code states that "in matters not regulated by law, usages shall apply". The potential for direct applicability of usages in this situation is still to be discussed. As stated in the doctrine, "according to para. (2), the usages apply only "in the cases not provided by the law", that is to say, to regulate any social relations that, by their very particular nature, "escaped" the legal regulations. It is not, therefore, about situations in which the existing legal regulations are not sufficient, which, as we have seen, are circumscribed by the application of common law, but it is about situations that do not actually have legal regulation" (Vasilescu et al., 2013). However, under the current legislative inflation, it is difficult to imagine an area of social life that completely escapes legal regulation. This is all the more so since the law, in the conception of civil law, is viewed as lato sensu and includes not only the acts adopted by the Parliament but also the orders, decisions, regulations, norms adopted by the central and local public administration.

Secundum legem usages shall apply on the grounds of an express provision of the law. In this respect, the new Civil Code, in the field of real estate, stipulates in Article 603 that "The right to property compels to the observance of environmental protection duties and the ensuring of good neighbourliness, to the observance of the other duties which, according to law or custom, belong to the owner".

Regarding contra legem usages, the question arises whether their applicability can be accepted. In other words, if in a matter governed by the law one may use a usage contrary to it. In our opinion this is possible. According to Article 1 paragraph (3) of the Civil Code "In matters governed by law, usages shall apply only to the extent that the law expressly addresses them". It is therefore possible that a certain field is legally regulated, but at the same time the law refers to the applicability of a usage (if any). In this case it will only apply if it complies with "public order and good morals" as stated by Article 1 para. (4) of the Civil Code.

Under the aspect of probation, Article 1 para. (5) of the Civil Code establishes the burden of proof of usages with regard to the one who invokes them. Their applicability is quite limited in this respect as well. Thus, the one who invokes a usage must first of all prove its existence. Therefore, it should be proven that a certain practice has been applied in a particular community for a long time. This applicability must be of sufficient duration to appreciate its rooting. Then the psychological element must be proven as well, in the sense that those who apply that practice consistently conform to it and accept its mandatory character.

The situation is much easier, from a probation point of view, if the usages are published in collections elaborated by the entities or bodies authorized in the field. However, in our opinion, this situation can only be encountered in the case of professional usages because only in this field there are authorized entities or bodies. 
Professional usages have been defined as "practices stemming from the pursuit of a profession or activity of production, trade or provision of services" (Ungureanu and Munteanu, 2013). When these usages are contained in elaborated collections of professional entities, they lose a specific character of the usage, namely they cease to be unwritten conduct rules. However, their insertion into collections does not turn them into law. They have a customary nature, being accepted by the members of that profession without the interference of the state power. Our civil regulation makes thus an important step in the unification of private law in the field of international trade.

Today, the efforts to code commercial customs and place them on a strong doctrinal support to distinguish them from local customs are known. International instruments adopted for this purpose include the Convention Relating to a Uniform Law on the International Sale of Goods - ULSIG or ULIS and the Convention Relating to a Uniform Law on the Formation of Contracts for the International Sale of Goods - ULEC or ULE. The new Romanian civil regulation, which recognizes these professional usages and gives them, under certain conditions, the status of a source of law, is a step forward on the way of unifying the international trade law. This unitary coding tends to be achieved not by means of rules imposed by the state apparatus but by recognizing some long-established practices in this field.

\section{Conclusions}

Concluding the findings of the present study, we can say that the new civil regulation is a progress in terms of regulating the sources of civil law and not a "return to the past," as some authors' claims. Even if apparently the recognition of the custom as a source of law would defeat the principle of legality and the principle of predictability of the law, a careful analysis of the legal provisions does not confirm this hypothesis. Due to the strict regulation of the conditions in which usages can be regarded as a source of law, their subordination to law and the difficulty of their probation, they will apply only in well-founded cases. From the point of view of the professional activity, the current regulation tends to unify the international trade customs, constituting a real progress in the field. Contrary to the views that provide for the removal of custom from the legal field, it obviously gains a growing preponderance, especially in international trade, environment, diplomacy relations, where the sovereign regulation power of the state actors is limited.

\section{References}

Alexandresco, D. (1926). Principiile dreptului civil (Principles of Civil Law): Encompassing the doctrine and jurisprudence up to date, as well as the best known, Romanian, French and German, etc. maxims, aphorisms, proverbs and legal rules, placed in the order of the civil code with their application in the various subjects of law. Volume 1, Atelierele Grafice "Socec \& Co.", Bucureşti, pp. 25-28.

Bederman, D. J. (2010). Custom as a Source of Law, Cambridge University Press, New York, p. 22. Beleiu, G. (2005). Drept civil român (Romanian Civil Law). Introducere în dreptul civil (Introduction to Civil Law). Subiectele dreptului civil (The subjects of Civil Law), Editura Universul Juridic, Bucureşti, pp. 44-45.

Beleiu, G. (1987). Drept civil (Civil Law). Teoria generala (General Theory). 
INTERNATIONAL JOURNAL OF ACADEMIC RESEARCH IN BUSINESS AND SOCIAL SCIENCES

Vol. 8, No. 5, May 2018, E-ISSN: 2222-6990 @ 2018 HRMARS

Cernea E., Molcuţ E. (1994). Istoria statului şi dreptului românesc (History of Romanian State and Law), Casa de editura şi de presa Şansa, Bucureşti.

Eminescu, Y. (1967). Tratat de drept civil (Civil Law Treatise). Partea Generala (General Part), vol. I, Ed. Academiei, Bucureşti, p. 72.

Schiller, A.A. (1938). Custom in Classical Roman Law, 24 VLR 268, , 1938, p. 270-271.

Ungureanu, O., Munteanu, C. (2013). Drept civil (Civil Law). Partea generala (General Part), Ed. Universul Juridic, Bucureşti, p. 52.

Vasilescu P., Diaconescu S., Reghini I. (2013). Introducere în dreptul civil (Introduction to Civil Law), Editura Hamangiu, Bucureşti, pp. 14-16. 